\title{
Diagnoza emisji głosu z wykorzystaniem wywiadu ustrukturyzowanego - implikacje praktyczne
}

Voice emission diagnosis using a structured interview: practical implications

Słowa kluczowe: diagnoza emisji głosu, metody diagnostyczne, wywiad ustrukturyzowany

Keywords: voice emission diagnosis, diagnostic methods, structured interview

\section{Diagnoza emisji głosu}

W celu przeprowadzenia wielowymiarowej diagnozy emisji głosu można wykorzystywać kilka różnych metod. Należy tutaj wymienić te, które stosowane są przez specjalistów (lekarzy, foniatrów, laryngologów, logopedów, trenerów emisji głosu itp.), a także te, które może zastosować każda osoba zainteresowana oceną swoich możliwości głosowych. W artykule skupię się na narzędziach/technikach przeznaczonych dla profesjonalistów:

1) badaniu przedmiotowym (w szczególności badaniu diagnostycznym cyklu wibracyjnego fałdów głosowych),

2) metodach akustycznego różnicowania zaburzeń głosu,

3) arkuszach do diagnozy jakości emisji głosu ${ }^{1}$.

Możliwe jest również dokonanie samooceny stanu głosu (zarówno mówionego, jak i śpiewanego) z zastosowaniem testów/arkuszy samoopisowych, w których badani określają występowanie trudności lub potwierdzają brak u siebie poszczególnych niedomogów głosowych. Mogą również samodzielnie wykonać badanie przy

* Uniwersytet Śląski w Katowicach, Wydział Filologiczny, Katedra Dydaktyki Języka i Literatury Polskiej, pl. Sejmu Śląskiego 1, 40-007 Katowice, e-mail: anna.guzy@us.edu.pl, https://orcid. org/0000-0002-6713-7293

1 Specjaliści do całościowej oceny wykorzystują również wyniki uzyskane ze skal samoopisowych, na przykład VHI. 
wykorzystaniu prostego oprogramowania komputerowego, które oceni jakość ich mowy (np. mogą sprawdzić swój maksymalny czas fonacji2).

Europejskie Towarzystwo Laryngologiczne w 2001 roku ustaliło protokół diagnostyczny w przypadku kompleksowej oceny traktu głosowego. Obejmuje on: wywiad, badanie przedmiotowe, ocenę odsłuchową głosu, badanie wideolaryngostroboskopowe, ocenę aerodynamiczną, badania akustyczne oraz samoocenę jakości głosu [Dejonckere i wsp., 2001, s. 78-82; zob. także: Niebudek-Bogusz, 2009].

Opracowano również standard postępowania logopedycznego w przypadku zaburzeń głosu [Wysocka i wsp., 2008]. Zaleca się w nim, aby logopeda (niezależnie od wywiadu wykonanego przez laryngologa czy foniatrę) przeprowadził własny wywiad, który pomoże mu uzyskać informacje na temat wcześniejszych trudności głosowych, jak również ich początku, dodatkowych schorzeń, przebiegu terapii. Zwraca się również uwagę na konieczność wykonania testu samooceny niesprawności głosowej. Właściwe badanie logopedyczne powinno obejmować ocenę poszczególnych sfer związanych z funkcjonowaniem głosowym: „postawa ciała, oddychanie, koordynacja oddechowo-fonacyjno-artykulacyjna, motoryka artykulacyjna, czynność rezonatorów nasady, natężenie głosu, wysokość głosu, tempo mowy" [Wysocka i wsp., 2008, s. 244]. W opracowaniu znajdziemy Kartę badania logopedycznego, która ułatwi diagnoście dokonanie oceny poszczególnych sprawności [Wysocka i wsp., 2008, s. 252-253].

Oprócz badania przedmiotowego i wywiadu wstępnego dokonywać można wielu obserwacji, jak również szczegółowych analiz, w celu pełnego określenia jakości emisji głosu badanego. Najbardziej precyzyjne metody badawcze wymagają specjalistycznej aparatury pomiarowej do rejestrowania zmian w zakresie pracy wibracyjnej fałdów głosowych. Zygmunt Pawłowski wyróżnia trzy główne metody badawcze w tym obszarze diagnostycznym: metody optyczne (m.in. stroboskopię, wideostroboskopię, wideokymografię, fotoglotografię, elektrolaryngografię), analizy akustyczne głosu (ultrasonografię, ocenę częstotliwości podstawowej, testową ocenę ciśnienia akustycznego głosu, wieloparametrową analizę mowy częstotliwości podstawowej), jak również metody elektryczne (elektrogrotografię) [więcej: Pawłowski, 2005, s. 85-115].

Można wyróżnić kilka metod akustycznego różnicowania zaburzeń głosu. Często stosuje się usystematyzowane skale. Najpowszechniejszą z nich jest opracowana przez Minoru Hirano [1981] skala Japońskiego Towarzystwa Logopedów i Foniatrów - GRBAS. W GRBAS określamy pięć parametrów: stopień chrypki (G - ang. grade of hoarseness), szorstkość ( $\mathrm{R}$ - ang. roughness), głos chuchający - powietrze w głosie (B - ang. breathiness), osłabienie głosu (A - ang. asthenic), napięcie głosu ( $\mathrm{S}$ - ang. strained) w czterostopniowej skali. Skala określa nasilenie danego

2 Por. przykładowo aplikację do prostego badania maksymalnego czasu fonacji: http://old.imp.lodz. pl/emisja_glosu/examinator/wstep_analiza.html\# (dostęp: 21.06.2019). 
parametru w następujący sposób: 0 - głos normalny, zaburzenie nie występuje, 1 - niewielki stopień nasilenia, 2 - umiarkowany stopień nasilenia, 3 - duży stopień nasilenia. Oprócz skali GRBAS stosuje się również metody oparte na obiektywnych obrazach analizy akustycznej, z wykorzystaniem spektrografu, sonografu czy z zapisem czasowym sygnału mowy [Świdziński, 2000]. Często analizy akustyczne wykonuje się przed i po obciążeniu głosu ${ }^{3}$. Ocena taka umożliwia opis parametrów fizycznych głosu. Analizie poddaje się kilka różnorodnych parametrów, najczęściej: średnią częstotliwość podstawową $(F 0)$, parametr zmian częstotliwości podstawowej (jitter), względną modulację amplitudy (shimmer), jak również stosunek szumu do sygnału [Sielska-Badurek, Niemczyk, 2015, s. 14-15; Olszewski, Nowosielska-Grygiel, 2017, s. 95-96].

Do diagnostyki jakości emisji głosu wykorzystuje się również analizę wybranych parametrów. W praktyce są to najczęściej: ocena pojemności życiowej (VC), maksymalny czas fonacji (MPT a), współczynnik s/z ratio oraz współczynnik DSI (współczynnik nasilenia dysfonii). W tabeli 1 dokonano charakterystyki opisywanych parametrów.

Jak wynika z charakterystyki parametrów, $V C$ może wpływać na różnice w wynikach $M P T[a]$. W celu wyeliminowania nieścisłości pomiarowej zaleca się określenie współczynnika fonacji $(P Q)$. Jest on ilorazem wartości $V C$ (uzyskanej w wyniku badania spirometrycznego) oraz MPT[a]. Średnie wartości $P Q$ dla kobiet wynoszą 125,8 ml/s, natomiast u mężczyzn $135 \mathrm{ml} / \mathrm{s}$ [Sielska-Badurek, Niemczyk, 2015, s. 14].

Oprócz opisanych metod akustycznych, badania fizykalnego, jak również z zastosowaniem aparatury pomiarowej, możemy wykorzystać skale i narzędzia diagnostyczne. Mogą mieć one charakter samoopisowy lub być wypełniane przez diagnostę - jak Karta badania logopedycznego czy Arkusz diagnozy emisji głosu. W praktyce klinicznej najczęściej stosowane są dwie skale: test samooceny niesprawności głosu (Voice Handicap Index - VHI) oraz skala dyskomfortu traktu głosowego (Vocal Tract Discomfort - VTD). Przyjrzyjmy się bliżej obu tym narzędziom.

VHI posiada wersję do oceny parametrów głosowych osób w mowie i śpiewie. Najpowszechniej stosowaną wersją jest VHI-30 do oceny głosu mówionego. Składa się on z 30 pytań, podzielonych na trzy skale: samoocenę stanu funkcjonalnego głosu (określającą to, w jaki sposób trudności głosowe utrudniają badanej osobie codzienne funkcjonowanie), samoocenę stanu emocjonalnego głosu (w której analizie poddany jest afekt osoby badanej, związany z jej głosem) oraz samoocenę stanu fizycznego głosu (w której oceniane jest występowanie poszczególnych trudności głosowych: zmiana barwy głosu, siła głosu, trudności oddechowe itp.). Badany ustosunkowuje się do każdego z 30 pytań, określając, jak bardzo dane stwierdzenie jest adekwatne do jego osoby. Stosowana jest pięciostopniowa skala, w której 0 oznacza, że nigdy, 1 - prawie nigdy, 2 - czasami, 3 - prawie zawsze, 4 - zawsze. Uzyskanie

3 Obciążenie głosowe polega na czytaniu przez osobę badaną dowolnego tekstu przez pół godziny. W pomieszczeniu, w którym odbywa się badanie, panuje szum biały (hałas) wynoszący $85 \mathrm{~dB}$. Więcej na ten temat: Świdziński, 2000. 
0-30 punktów oznacza wynik niski (brak lub występowanie nieznacznych trudności głosowych), 31-60, oznacza, że badany ma średnie trudności ze swoim głosem. Wynik mieszczący się w przedziale 61-120 oznacza występowanie dużych trudności głosowych. W takim przypadku zaleca się natychmiastową wizytę u specjalisty.

Tabela 1. Wybrane parametry oceny jakości głosu i ich charakterystyka

\begin{tabular}{|c|c|c|c|}
\hline $\begin{array}{c}\text { Pojemność życiowa } \\
\text { (VC) }\end{array}$ & $\begin{array}{c}\text { Maksymalny czas } \\
\text { fonacji (MPT) }\end{array}$ & Współczynnik s/z & Współczynnik DSI \\
\hline \begin{tabular}{|l|} 
Nie określa \\
bezpośrednio czasu \\
fonacji, umożliwia \\
jednak oszacowanie \\
powietrza, które może \\
być zużyte podczas \\
fonacji. Średnie \\
wartości pojemności \\
życiowej płuc wynoszą \\
4800 ml dla mężczyzn \\
oraz 3500 ml dla kobiet. \\
Wartość tego \\
parametru mierzona \\
jest za pomocą \\
spirometru \\
[Wiskirska-Woźnica, \\
2008, s. 45]. \\
Wartość VC zależy \\
od wieku (u dzieci \\
jest niższa) oraz płci, \\
jak również schorzeń \\
w obrębie dolnych \\
dróg oddechowych \\
[Sielska-Badurek, \\
Niemczyk, 2015, s. 14].
\end{tabular} & $\begin{array}{l}\text { Jest to:„zdolność } \\
\text { maksymalnego } \\
\text { fonowania samogłoski } \\
\text { [a] podczas } \\
\text { pełnego wydechu” } \\
\text { [Wiskirska-Woźnica, } \\
\text { 2008, s. 45]. Wynik } \\
\text { MPT podaje się } \\
\text { W sekundach. } \\
\text { Według różnych } \\
\text { autorów wartość } \\
\text { MCF wynosi średnio } \\
\text { 17,25-34,6 sekund } \\
\text { dla mężczyzn oraz } \\
\text { 12,1-16,5 sekundy dla } \\
\text { kobiet [Halama, Raes, } \\
\text { 1998, s. 39-45]. } \\
\text { Wartość MPT zależy } \\
\text { od pojemności } \\
\text { życiowej płuc VC. }\end{array}$ & $\begin{array}{l}\text { Określa stosunek } \\
\text { (iloraz) długości czasu } \\
\text { fonacji artykulacji } \\
\text { głoski bezdźwięcznej } \\
\text { [s] do czasu } \\
\text { artykulacji głoski } \\
\text { dźwięcznej [z]. W celu } \\
\text { uwiarygodnienia } \\
\text { wyniku próbę fonacji } \\
\text { głosek powtarza się } \\
\text { dwukrotnie. Aby } \\
\text { wyliczyć wartość } \\
\text { współczynnika, } \\
\text { dzielimy najdłuższy } \\
\text { czas fonacji głoski [s] } \\
\text { przez najdłuższy czas } \\
\text { fonacji głoski [z]. } \\
\text { Wynik 1,0 oznacza brak } \\
\text { patologii i wskazuje } \\
\text { na właściwą zdolność } \\
\text { oddechową. Wielkość } \\
\text { współczynnika } \\
\text { 1,2 i więcej może } \\
\text { wskazywać } \\
\text { na patologiczny stan } \\
\text { fałdów głosowych } \\
\text { [Deem, Miller, 2000; } \\
\text { McAfee, Shipley, 2009, } \\
\text { s. 395]. }\end{array}$ & $\begin{array}{l}\text { Współczynnik określa } \\
\text { nasilenie dysfonii, } \\
\text { a jego wartość uznaje } \\
\text { się za obiektywną. } \\
\text { Uzyskuje się } \\
\text { go z parametrów } \\
\text { analizy akustycznej } \\
\text { i aerodynamicznej, } \\
\text { takich jak: } \\
\text { maksymalny czas } \\
\text { fonacji, maksymalna } \\
\text { częstotliwość głosu } \\
\text { (F max), minimalne } \\
\text { natężenie głosu (I min) } \\
\text { i jitter [więcej na ten } \\
\text { temat: Sielska-Badurek, } \\
\text { Niemczyk, 2015]. } \\
\text { Współczynnik analizuje } \\
\text { się następująco: } \\
\text { powyżej 4.2 bez cech } \\
\text { dysfonii, 1.81-4.2 lekka } \\
\text { dysfonia, -1.2-1.8 } \\
\text { umiarkowana dysfonia, } \\
\text { a wynik niższy lub } \\
\text { równy -1.2 oznacza } \\
\text { ciężką dysfonię. }\end{array}$ \\
\hline
\end{tabular}

Źródło: opracowanie własne.

Skala dyskomfortu traktu głosowego (Vocal Tract Discomfort - VTD) składa się z szeregu doznań, które mogą być obserwowane w obrębie gardła i krtani: pieczenia, napięcia, suchości, bólu, drapania, tkliwości (bolesności przy dotyku), podrażnienia oraz uczucia kluski w gardle. Zadaniem badanego jest określenie częstotliwości (od 0 - nigdy do 6 - zawsze) występowania danej trudności oraz stopnia nasilenia (od 0 - brak do 6 - duże nasilenie). Im więcej trudności obserwowanych z większą częstotliwością, tym większa skala dyskomfortu traktu głosowego u badanego [Woźnicka i wsp., 2012a). 
Zarówno test VHI, jak i skala VTD stanowią cenne narzędzia diagnostyczne o potwierdzonej wartości diagnostycznej i rzetelności [Niebudek-Bogusz i wsp., 2007].

Oprócz skal samoopisowych do diagnozy wykorzystywane są również autorskie narzędzia przygotowane przez logopedów czy trenerów emisji głosu [np. Guzy, 2012; Kisiel, 2012]. Narzędzia takie stosowane są na ogół do diagnozy indywidualnej. Przykładowo, Arkusz diagnozy emisji głosu (ADE) składa się z różnorodnych zadań, należących do dziewięciu sfer: samoocena, postawa, artykulacja, rezonans, oddychanie, fonacja, motoryka aparatu artykulacyjnego, prozodia, głosowe przedstawienie tekstu. Arkusz zawiera ponadto propozycje pytań do wywiadu wstępnego. Badanie z wykorzystaniem tego narzędzia trwa około 20-25 minut [szczegółowy opis narzędzia: Guzy, 2012, s. 120-136].

Mając na uwadze to, że wywiad wstępny stanowi podstawę do dalszej diagnostyki, jest jej niezbędnym i fundamentalnym elementem, proponuję wykorzystanie schematu ustrukturyzowanego wywiadu, który można wykorzystać podczas zbierania wstępnych danych.

\section{Wywiad ustrukturyzowany}

Przed zaprezentowaniem mojej propozycji wywiadu, chciałam zaznaczyć, że proponowane narzędzie nie jest wywiadem ustrukturalizowanym, czyli standaryzowanym w klasycznym rozumieniu. Nie wyliczano własności psychometrycznych tego narzędzia, takich jak rzetelność czy trafność [Stemplewska-Żakowicz, 2011, s. 64]. Wywiad $\mathrm{w}$ proponowanym kształcie nie jest jedynym narzędziem w przypadku diagnozy emisji głosu, stanowi element wstępny, w odróżnieniu od ustrukturalizowanych narzędzi psychologicznych, przykładowo wywiadu klinicznego do badania całościowego danego parametru [por. First i wsp., 2010]. Wywiad określiłam mianem „ustrukturyzowanego", ponieważ ma określoną strukturę, na którą składają się różnorodne obszary związane z funkcjonowaniem osoby badanej w kontekście występowania u niej problemów z emisją głosu. Proponowana struktura (w tym także kolejność zadawanych pytań) pozwala na bardziej ekonomiczne dysponowanie czasem podczas rozmowy, ułatwia diagnoście zorientowanie się w kluczowych sferach, które mogą mieć istotny wpływ na jakość emisji głosu u diagnozowanej osoby, a także lepsze zrozumienie natury jej problemów (jeśli takie zgłasza). Ułatwieniem podczas zbierania danych może być uproszczony arkusz zapisu odpowiedzi (por. załącznik 1).

Przy konstruowaniu narzędzia wzięto pod uwagę czynniki zewnętrzne i wewnętrzne, o których wiadomo, że mają wpływ na jakość głosu. Uzupełniono je o poszerzoną grupę czynników psychologicznych. Jak wskazują badania, aż 57\% zaburzeń głosu ma tło czynnościowe [Sielska-Badurek, Niemczyk, 2015, s. 12], a zatem podczas zbierania danych (szczególnie wstępnych), nie możemy zapomnieć o pytaniach, które pomogą nam rozważyć, czy objawy nie mają podłoża psychogennego. Z prowadzonych 
przeze mnie wśród nauczycieli badań wynika ${ }^{4}$, że takie czynniki, jak lęk (jako cecha i jako stan), stres (poziom odczuwanego stresu w ciągu ostatniego miesiąca), zadowolenie z życia, wypalenie zawodowe, stan zdrowia, samoocena czy zachowania zdrowotne, mają istotny wpływ na jakość emisji głosu badanych. Pytania związane z tymi konstruktami warto zatem wpleść w wywiad wstępny, a dodatkowo pogłębić wywiad w przypadku, gdy badania fizykalne nie będą wyjaśniały powodów występowania u badanej osoby zgłaszanych objawów. Dodatkowym czynnikiem upewniającym nas w czynnościowej etiologii zaburzeń może być wynik testu VHI, jeśli diagnozowany pacjent uzyska najwyższy wynik w skali: samoocena stanu emocjonalnego.

W czasie diagnozy emisji głosu w fazie zbierania danych do wywiadu należy zgromadzić możliwie jak najwięcej informacji z zakresu: danych podstawowych, stanu zdrowia i nawyków zdrowotnych, formy i warunków pracy głosem, zgłaszanych problemów głosowych, jak również zmiennych psychologicznych. Na samym początku warto przeprowadzić krótki (jedno-, dwuminutowy) instruktaż: poinformować o przebiegu całego postępowania, jak również zmotywować do precyzyjnego odpowiadania na pytania. Zdarza się bowiem, że badani podają bardzo dużo informacji, które na tym etapie mogą utrudniać zebranie potrzebnych danych. Przykładowo możemy rozpocząć następująco:

Za chwilę zadam Pani/Panu szereg pytań dotyczących różnych aspektów Pani/Pana życia: zdrowia, nawyków czy pracy. Informacje te są niezwykle istotnym elementem diagnostycznym. Niektóre pytania mogą wydawać się dziwne, a nawet śmieszne, ale zostały dobrane w taki sposób, aby poznać szereg różnych obszarów Pani/Pana funkcjonowania związanych z emisją głosu. Zależy mi na szczerych odpowiedziach. Pomogą mi one lepiej poznać Panią/ Pana oraz obserwowane i odczuwane przez Panią/Pana trudności głosowe. Gdyby coś było niejasne, proszę dopytywać. Czy możemy zacząć? Czy jest Pan/Pani gotowa?

I. Dane podstawowe. W tej części pytamy o wiek, lata pracy w zawodzie (szczególnie, jeśli związany jest ze znacznym wysiłkiem głosowym), wizyty u takich specjalistów, jak foniatra, laryngolog, audiolog, ortodonta. Pytamy również o wyniki badań, jeśli były przeprowadzone, oraz powody wizyt. Dopytujemy o początek trudności głosowych, ewentualne choroby narządu głosu w rodzinie, poprzednie wizyty u logopedy czy trenera emisji głosu.

II. Warunki i higiena pracy. Pytamy o to, ile godzin dziennie badany posługuje się głosem w pracy (także w domu), do ilu osób mówi (czy jest zmuszony mówić głośniej niż zwykle), jak długo jest zmuszony mówić bez przerwy lub z niewielkimi przerwami, czy ma nagłośnienie, czy warunki jego pracy nie uległy ostatnio zmianie, jakie ma warunki do pracy głosem: akustyka pomieszczenia, poziom hałasu, nawilżenie powietrza, temperatura w pomieszczeniu (równiė̇

4 Badania były prowadzone w latach 2012-2017. Indywidualnym diagnozom głosu poddałam około czterystu nauczycieli na różnych etapach kształcenia na terenie województwa śląskiego oraz dolnośląskiego. 
czy pracuje w klimatyzowanym pomieszczeniu). Dopytujemy o pracę w szkodliwych warunkach (pyły, związki azbestu itp.).

III. Nawyki zdrowotne. Na początku pytamy o palenie papierosów, zarówno czynne, jak i bierne (dopytujemy, jak długo pali, ile). Pytamy o przyjmowane leki (szczególnie na alergię, diuretyczne, hormonalne), o tryb życia (długość snu, aktywność fizyczną, nawadnianie organizmu, dietę), o to, kiedy w przypadku występowania trudności z głosem, na przykład przy zapaleniu gardła czy chrypce, ankietowany udaje się po pomoc (natychmiast, po kilku dniach czy kiedy uniemożliwi mu to pracę), czy zna i wykonuje ćwiczenia z zakresu emisji głosu, czy nawilża gardło podczas pracy głosem.

IV. Stan zdrowia. Prosimy o dokonanie samooceny stanu zdrowia (przykładowo polecamy, aby diagnozowany ocenił stan swojego zdrowia na skali od 0 do 4, gdzie 0 oznacza bardzo zły stan zdrowia, a 4 idealny). Ponadto dopytujemy o choroby przewlekłe, które mogą mieć największy wpływ na występowanie trudności głosowych (alergie, astma, refluks, nerwica, depresja, choroby endokrynologiczne, problemy z szyjnym odcinkiem kręgosłupa, zabiegi operacyjne, w szczególności związane z narządem głosu, układem oddechowym, słuchem, ale także endokrynologiczne, zabiegi operacyjne w obrębie szyi).

V. Problemy głosowe. Dopytujemy diagnozowanego zarówno o częstość występowania, jak i nasilenie problemów głosowych (ułatwieniem może być zastosowanie skali od 0 do 4, gdzie 0 oznacza wcale/brak, a 4 bardzo często/bardzo silne). Pytamy o każdy element osobno: występowanie chrypki, bezgłosu, załamywania się głosu, zmianę barwy głosu, uczucie suchości w gardle/ustach, męczliwość głosu, dyskomfort w gardle i krtani (np. ból, pieczenie).

VI. Zmienne psychologiczne. Również tutaj sugeruję zorientowanie się w zakresie częstości występowania oraz nasilenia, zgodnie ze skalą zaproponowaną do oceny problemów głosowych (od 0 do 4). Dopytujemy o: wypalenie zawodowe/niechęć do pracy, odczuwanie stresu w ciągu ostatniego tygodnia/ miesiąca, odczuwanie lęku, zadowolenie z życia. Ponadto pytamy o samoocenę oraz zadowolenie z brzmienia własnego głosu w skali od 0 (bardzo niska/niska) do 4 (bardzo wysoka/pełne zadowolenie z brzmienia głosu).

Rozmowę diagnostyczną możemy zakończyć następująco:

Bardzo dziękuję za cierpliwość, szczere i wyczerpujące odpowiedzi. Mimo że starałem/starałam się zapytać o wszystkie istotne elementy, być może coś pominąłem/pominęłam. Czy jest coś, co wydaje się jeszcze Pani/Panu ważne? Jeśli nie, bardzo dziękuję. Przejdźmy do dalszego etapu diagnozy5.

5 W zależności od potrzeb i możliwości w kolejnym etapie diagnozowany wypełnia kwestionariusze samoopisowe lub są mu wykonywane inne pomiary czy badanie fizykalne. 
Interpretacja uzyskanych danych z wywiadu może przebiegać dwutorowo: ilościowo i jakościowo. Parametry IV-VI, a zatem stan zdrowia, problemy głosowe, zmienne psychologiczne, oceniane są na skali od 0 do 4 . Im więcej uzyskanych punktów w poszczególnych sferach, tym gorszy stan zdrowia diagnozowanego, większe trudności głosowe (częściej występujące), jak również słabsza kondycja psychiczna (większe odczucie lęku, stresu, zmęczenia pracą, wypalenia), a także mniejsze poczucie zasobów własnych (zadowolenia z życia).

\section{Podsumowanie i wnioski}

W praktyce klinicznej można wykorzystywać różnorodne narzędzia diagnostyczne. Niewątpliwie jednym $z$ istotniejszych elementów jest wywiad wstępny. W formie zaproponowanej w artykule może być stosowany przez specjalistów: logopedów, trenerów emisji głosu, foniatrów czy lekarzy laryngologów. W zależności od dalszej diagnostyki i jej celu można wykorzystać go w całości lub w części. W przypadku chęci dokonania dogłębnej analizy zaleca się przeprowadzenie wywiadu w całości, co umożliwi zebranie możliwie pełnych danych diagnostycznych, a następnie projektowanie dalszych działań (na przykład terapii czy prowadzenia rozmowy profilaktycznej).

\section{Załącznik 1. Arkusz ustrukturyzowanego wywiadu wstępnego do diagnozy emisji głosu}

Imię i nazwisko:

Data badania:

I. Dane podstawowe

\begin{tabular}{|l|l|l|}
\hline \multicolumn{1}{|c|}{ Parametr } & & \multicolumn{1}{c|}{ Uwagi } \\
\hline $\begin{array}{l}\text { Wiek: } \\
\text { Obecnie wykonywany zawód: }\end{array}$ & & \\
\hline $\begin{array}{l}\text { Lata pracy w zawodzie wymagającym } \\
\text { wysitku głosowego: }\end{array}$ & & \\
\hline $\begin{array}{l}\text { Wizyty u specjalistów: } \\
\text { - foniatra }\end{array}$ & Tak/Nie Cel wizyty: & \\
- laryngolog & Tak/Nie Cel wizyty: & \\
- oudodog & Tak/Nie Cel wizyty: & \\
- logopeda & Tak/Nie Cel wizyty: & \\
- trener emisji głosu & Tak/Nie Cel wizyty: \\
\hline $\begin{array}{l}\text { Początek trudności głosowych (kiedy? } \\
\text { czego dotyczyły?) }\end{array}$ & & \\
\hline
\end{tabular}




\begin{tabular}{|l|l|l|}
\hline \multicolumn{1}{|c|}{ Parametr } & & Uwagi \\
\hline $\begin{array}{l}\text { Największe nasilenie trudności } \\
\text { głosowych (kiedy?, czego dotyczyły?) }\end{array}$ & & \\
\hline $\begin{array}{l}\text { Ostatnie trudności głosowe (kiedy?, } \\
\text { czego dotyczyły?) }\end{array}$ & & \\
\hline Choroby narządu głosu w rodzinie & $\begin{array}{l}\text { Tak/Nie } \\
\text { Jakie? }\end{array}$ & \\
\hline
\end{tabular}

\section{Warunki i higiena pracy}

\begin{tabular}{|l|l|l|}
\hline \multicolumn{1}{|c|}{ Parametr } & \multicolumn{1}{c|}{ Uwagi } \\
\hline $\begin{array}{l}\text { Średnia liczba godzin posługiwania } \\
\text { się głosem w pracy oraz w domu }\end{array}$ & $\begin{array}{l}\text { Praca: Do ilu średnio osób: } \\
\text { Dom: Do ilu średnio osób: }\end{array}$ & \\
\hline Nagłośnienie & Tak/Nie & \\
\hline Akustyka pomieszczenia & Właściwa/Niedogodna & \\
\hline Poziom hałasu & Panuje cisza/Optymalny/Zbyt głośno & \\
\hline Nawilżenie powietrza & Właściwe/Zbyt sucho & \\
\hline Temperatura powietrza & Odpowiednia/Zbyt zimno/Zbyt ciepło & \\
\hline $\begin{array}{l}\text { Praca w klimatyzowanym } \\
\text { pomieszczeniu }\end{array}$ & Tak/Nie & \\
\hline $\begin{array}{l}\text { Praca w warunkach szkodliwych } \\
\text { (pyły, związki azbestu) }\end{array}$ & Tak/Nie & \\
\hline
\end{tabular}

III. Nawyki zdrowotne

\begin{tabular}{|c|c|c|}
\hline Parametr & & Uwagi \\
\hline $\begin{array}{l}\text { Palenie papierosów } \\
\text { Palenie bierne }\end{array}$ & $\begin{array}{l}\text { Tak/Nie Jak długo? ___ Ile? } \\
\text { Tak/Nie Jak długo? }\end{array}$ & \\
\hline \multicolumn{3}{|l|}{$\begin{array}{l}\text { Przyjmowane leki (na alergię, diuretyki, } \\
\text { hormonalne) }\end{array}$} \\
\hline Choroby endokrynologiczne & Tak/Nie Jak długo? & \\
\hline \multicolumn{3}{|l|}{ Średnia liczba godzin snu na dobę } \\
\hline \multicolumn{3}{|l|}{$\begin{array}{l}\text { Średnia liczba wypijanej wody w ciągu } \\
\text { doby - nawodnienie organizmu }\end{array}$} \\
\hline $\begin{array}{l}\text { Po jakim czasie w przypadku } \\
\text { wystąpienia trudności z głosem } \\
\text { (chrypka, ból gardła) uda się Pan/Pani } \\
\text { do lekarza }\end{array}$ & $\begin{array}{l}\text { Od razu } \\
\text { Po kilku dniach } \\
\text { Gdy uniemożliwi mi to pracę } \\
\text { Inne } \\
\end{array}$ & \\
\hline $\begin{array}{l}\text { Czy zna Pan/Pani ćwiczenia z zakresu } \\
\text { emisji głosu (np. rozgrzewkę głosową, } \\
\text { ćwiczenia oddechowe itp.) }\end{array}$ & Tak/Nie & \\
\hline $\begin{array}{l}\text { Czy wykonuje Pan/Pani ćwiczenia } \\
\text { z zakresu emisji głosu? }\end{array}$ & \begin{tabular}{|l} 
Tak/Nie \\
Jak często?
\end{tabular} & \\
\hline $\begin{array}{l}\text { Czy podczas pracy głosem stara się } \\
\text { Pan/Pani regularnie nawilżać gardło } \\
\text { (np. pijąc wodę?) }\end{array}$ & Tak/Nie & \\
\hline
\end{tabular}




\section{Stan zdrowia}

\begin{tabular}{|c|c|c|c|c|c|c|}
\hline \multicolumn{6}{|c|}{ Parametr } & \multirow[t]{2}{*}{ Uwagi } \\
\hline \multirow{2}{*}{$\begin{array}{l}\text { Proszę na skali od } 0 \text { do } 4 \text { ocenić } \\
\text { stan swojego zdrowia, gdzie } \\
0 \text { oznacza bardzo zły stan } \\
\text { zdrowia, } 4 \text { natomiast idealny }\end{array}$} & 4 & 3 & 2 & 1 & 0 & \\
\hline & $\begin{array}{l}\text { bardzo } \\
\text { zły }\end{array}$ & zły & $\begin{array}{l}\text { raczej } \\
\text { dobry }\end{array}$ & bardzo dobry & idealny & \\
\hline \multirow[t]{2}{*}{ Występowanie alergii } & 0 & 1 & 2 & 3 & 4 & \\
\hline & nigdy & czasami & często & bardzo często & zawsze & \\
\hline \multirow[t]{2}{*}{ Nasilenie alergii } & 0 & 1 & 2 & 3 & 4 & \\
\hline & brak & małe & średnie & duże & bardzo duże & \\
\hline \multirow[t]{2}{*}{ Występowanie astmy } & 0 & 1 & 2 & 3 & 4 & \\
\hline & nigdy & czasami & często & bardzo często & zawsze & \\
\hline \multirow[t]{2}{*}{ Nasilenie astmy } & 0 & 1 & 2 & 3 & 4 & \\
\hline & brak & małe & średnie & duże & bardzo duże & \\
\hline \multirow[t]{2}{*}{ Występowanie refluksu } & 0 & 1 & 2 & 3 & 4 & \\
\hline & nigdy & czasami & często & bardzo często & zawsze & \\
\hline \multirow[t]{2}{*}{ Nasilenie refluksu } & 0 & 1 & 2 & 3 & 4 & \\
\hline & brak & małe & średnie & duże & bardzo duże & \\
\hline \multirow[t]{2}{*}{ Występowanie nerwicy } & 0 & 1 & 2 & 3 & 4 & \\
\hline & nigdy & czasami & często & bardzo często & zawsze & \\
\hline \multirow[t]{2}{*}{ Nasilenie nerwicy } & 0 & 1 & 2 & 3 & 4 & \\
\hline & brak & małe & średnie & duże & bardzo duże & \\
\hline \multirow{2}{*}{$\begin{array}{l}\text { Występowanie alergii/depresji/ } \\
\text { dystymii/obniżonego nastroju }\end{array}$} & 0 & 1 & 2 & 3 & 4 & \\
\hline & nigdy & czasami & często & bardzo często & zawsze & \\
\hline \multirow{2}{*}{\begin{tabular}{|l|} 
Nasilenie alergii/depresji/ \\
dystymii/obniżonego nastroju
\end{tabular}} & 0 & 1 & 2 & 3 & 4 & \\
\hline & brak & małe & średnie & duże & bardzo duże & \\
\hline \multirow{2}{*}{$\begin{array}{l}\text { Problemy z szyjnym odcinkiem } \\
\text { kręgosłupa }\end{array}$} & 0 & 1 & 2 & 3 & 4 & \\
\hline & nigdy & czasami & często & bardzo często & zawsze & \\
\hline \multirow{2}{*}{$\begin{array}{l}\text { Nasilenie problemów z szyjnym } \\
\text { odcinkiem kręgosłupa }\end{array}$} & 0 & 1 & 2 & 3 & 4 & \\
\hline & brak & małe & średnie & duże & bardzo duże & \\
\hline
\end{tabular}

\section{Problemy głosowe}

\begin{tabular}{|c|c|c|c|c|c|c|}
\hline \multicolumn{6}{|c|}{ Parametr } & \multirow[t]{2}{*}{ Uwagi } \\
\hline \multirow[t]{2}{*}{ Występowanie chrypki } & 0 & 1 & 2 & 3 & 4 & \\
\hline & nigdy & Czasami & często & bardzo często & zawsze & \\
\hline \multirow[t]{2}{*}{ Nasilenie chrypki } & 0 & 1 & 2 & 3 & 4 & \\
\hline & brak & małe & średnie & duże & bardzo duże & \\
\hline \multirow[t]{2}{*}{ Występowanie bezgłosu } & 0 & 1 & 2 & 3 & 4 & \\
\hline & nigdy & czasami & często & bardzo często & zawsze & \\
\hline \multirow[t]{2}{*}{ Załamywanie się głosu } & 0 & 1 & 2 & 3 & 4 & \\
\hline & nigdy & czasami & często & bardzo często & zawsze & \\
\hline \multirow[t]{2}{*}{ Nasilenie załamywania się głosu } & 0 & 1 & 2 & 3 & 4 & \\
\hline & brak & małe & średnie & duże & bardzo duże & \\
\hline
\end{tabular}


Diagnoza emisji głosu z wykorzystaniem wywiadu ustrukturyzowanego - implikacje praktyczne • 89

\begin{tabular}{|c|c|c|c|c|c|c|}
\hline \multicolumn{6}{|c|}{ Parametr } & \multirow[t]{2}{*}{ Uwagi } \\
\hline \multirow[t]{2}{*}{ Zmiana barwy głosu } & 0 & 1 & 2 & 3 & 4 & \\
\hline & nigdy & Czasami & często & bardzo często & zawsze & \\
\hline \multirow[t]{2}{*}{ Nasilenie zmiany barwy głosu } & 0 & 1 & 2 & 3 & 4 & \\
\hline & brak & małe & średnie & duże & bardzo duże & \\
\hline \multirow{2}{*}{$\begin{array}{l}\text { Występowanie uczucia suchości } \\
\text { w gardle }\end{array}$} & 0 & 1 & 2 & 3 & 4 & \\
\hline & nigdy & czasami & często & bardzo często & zawsze & \\
\hline \multirow{2}{*}{$\begin{array}{l}\text { Nasilenie uczucia suchości } \\
\text { w gardle }\end{array}$} & 0 & 1 & 2 & 3 & 4 & \\
\hline & brak & małe & średnie & duże & bardzo duże & \\
\hline \multirow[t]{2}{*}{ Męczliwość głosu } & 0 & 1 & 2 & 3 & 4 & \\
\hline & nigdy & czasami & często & bardzo często & zawsze & \\
\hline \multirow[t]{2}{*}{ Nasilenie odczucia } & 0 & 1 & 2 & 3 & 4 & \\
\hline & brak & małe & średnie & duże & bardzo duże & \\
\hline \multirow{2}{*}{$\begin{array}{l}\text { Występowanie dyskomfortu } \\
\text { w obrębie gardła i krtani (np. } \\
\text { ból, pieczenie) }\end{array}$} & 0 & 1 & 2 & 3 & 4 & \\
\hline & nigdy & czasami & często & bardzo często & zawsze & \\
\hline \multirow[t]{2}{*}{ Nasilenie dyskomfortu } & 0 & 1 & 2 & 3 & 4 & \\
\hline & brak & małe & średnie & duże & bardzo duże & \\
\hline
\end{tabular}

\section{Zmienne psychologiczne}

\begin{tabular}{|c|c|c|c|c|c|c|}
\hline \multicolumn{6}{|c|}{ Parametr } & \multirow[t]{2}{*}{ Uwagi } \\
\hline \multirow{2}{*}{$\begin{array}{l}\text { Odczucie wypalenia } \\
\text { zawodowego/chroniczne } \\
\text { zmęczenie pracą }\end{array}$} & 0 & 1 & 2 & 3 & 4 & \\
\hline & nigdy & czasami & często & bardzo często & zawsze & \\
\hline \multirow{2}{*}{$\begin{array}{l}\text { Nasilenie odczucia wypalenia } \\
\text { zawodowego/chronicznego } \\
\text { zmęczenia pracą }\end{array}$} & 0 & 1 & 2 & 3 & 4 & \\
\hline & brak & małe & średnie & duże & bardzo duże & \\
\hline \multirow[t]{2}{*}{ Odczuwanie stresu } & 0 & 1 & 2 & 3 & 4 & \\
\hline & nigdy & czasami & często & bardzo często & zawsze & \\
\hline \multirow[t]{2}{*}{ Nasilenie odczuwania stresu } & 0 & 1 & 2 & 3 & 4 & \\
\hline & brak & małe & średnie & duże & bardzo duże & \\
\hline \multirow{2}{*}{$\begin{array}{l}\text { Odczuwanie lęku (np. } \\
\text { związanego z pracą oraz } \\
\text { codziennym życiem) }\end{array}$} & 0 & 1 & 2 & 3 & 4 & \\
\hline & nigdy & czasami & często & bardzo często & zawsze & \\
\hline \multirow[t]{2}{*}{ Nasilenie odczucia lęku } & 0 & 1 & 2 & 3 & 4 & \\
\hline & brak & małe & średnie & duże & bardzo duże & \\
\hline \multirow[t]{2}{*}{ Zadowolenie z życia } & 0 & 1 & 2 & 3 & 4 & \\
\hline & brak & małe & średnie & duże & bardzo duże & \\
\hline \multirow{2}{*}{$\begin{array}{l}\text { Zadowolenie z brzmienia } \\
\text { własnego głosu }\end{array}$} & 0 & 1 & 2 & 3 & 4 & \\
\hline & brak & małe & średnie & duże & bardzo duże & \\
\hline
\end{tabular}


Literatura

Deem J., Miller L., 2000, Manual of Voice Therapy, Austin: Pro-Ed.

Dejonckere P.H., Bradley P., Clemente P., Cornut P., Crevier-Buchman L., Friedrich G., Van de Heyning P., Remacle M., Woisard V, 2001, A basic protocol for functional assessment of voice patology, especially for investigating the efficacy of (phonosurgical) treatments and evaluating new assessment techniques, „European Archives of Oto-Rhino-Laryngology”, vol. 258, s. 77-82.

First M.B., Gibbon M., Spitzer R.L., Wiliams J.B.W., Smith L., 2010, Ustrukturalizowany wywiad kliniczny do badania zaburzeń osobowości z osi II DSM-IV, Warszawa: Pracownia Testów Psychologicznych.

Guzy A., 2012, Jak określać problemy emisji głosu? Propozycja wykorzystania Arkusza Diagnozy Emisji Głosu (ADE), „Forum Logopedyczne”, nr 20, s. 120-136.

Halama A.R., Raes J., 1998, Pomiar maksymalnego czasu fonacji jako prosta próba oceny zaburzenia głosu, [w:] H. Mierzejewska, M. Przybysz-Piwkowa (red.), Zaburzenia głosu - badanie - diagnozowanie - metody usprawniania, Warszawa: Wydawnictwo DIG, s. 39-45.

Hirano M., 1981, Clinical Examination of Voice, New York: Springer.

Kisiel M., 2012, Emisja i higiena głosu w pracy dydaktyczno-wychowawczej nauczyciela, Dąbrowa Górnicza: Wyższa Szkoła Biznesu.

McAfee J.G., Shipley K.G., 2009, Assessment in Speach-Language Pathology, Clifton Park: Delmar Cengage Learning.

Niebudek-Bogusz E., 2009, Postępowanie $w$ dysfoniach zawodowych w krajach Unii Europejskiej i na świecie, „Medycyna Pracy”, nr 60(2), s. 151-158.

Niebudek-Bogusz E., Woźnicka E., Kuzańska A., Śliwińska-Kowalska M., 2007, Ocena zaburzeń głosu u nauczycieli za pomoca wskaźnika niepetnosprawności głosowej (Voice Handicap Index - VHI), „Medycyna Pracy”, vol. 58(5), s. 393-402.

Olszewski J., Nowosielska-Grygiel J., 2017, Nowe metody diagnostyczne oceny czynności głosu dla potrzeb foniatry i logopedy, „Logopaedica Lodziensia”, nr 1, s. 91-99.

Pawłowski Z., 2005, Foniatryczna diagnostyka wykonawstwa emisji głosu śpiewaczego i mówionego, Kraków: Oficyna Wydawnicza Impuls.

Sielska-Badurek E., Niemczyk K., 2015, Postępowanie diagnostyczne w zaburzeniach głosu, „Polski Przegląd Otolaryngologiczny", t. 4, nr 2, s. 12-18.

Stemplewska-Żakowicz K., 2011, Diagnoza psychologiczna. Diagnozowanie jako kompetencja profesjonalna, Gdańsk: Gdańskie Wydawnictwo Psychologiczne.

Świdziński P., 2000, Obiektywna metoda akustycznego różnicowania zaburzeń głosu, „Nowa Medycyna", nr 3, http://www.czytelniamedyczna.pl/1288,obiektywna-metoda-akustycznegoroznicowania-zaburzen-glosu.html (dostęp: 5.07.2019).

Wiskirska-Woźnica B., 2008, Kliniczna ocena czynności narządu głosu, [w:] A. Obrębowski (red.), Narząd głosu i jego znaczenie w komunikacji społecznej, Poznań: Wydawnictwo Naukowe Uniwersytetu Medycznego, s. 42-49.

Woźnicka E., Niebudek-Bogusz E., Kwiecień J., Wiktorowicz J., Śliwińska-Kowalska M., 2012a, Applicability of the vocal tract discomfort (VTD) scale in evaluating the effects of the voice therapy of occupational voice disorders, „Medycyna Pracy”, vol. 63, s. 141-152.

Woźnicka E., Niebudek-Bogusz E., Wiktorowicz J., Śliwińska-Kowalska M., 2012b, Applicability of the Vocal Tract Discomfort (VTD) scale in the diagnostics of occupational dysphonia, "Logopedia Phoniatrica”, vol. 37(4), s. 151-157.

Wysocka M., Skoczylas A., Szkiełkowska A., Mularzuk M., 2008, Standard postępowania logopedycznego w przypadku zaburzeń głosu, „Logopedia”, nr 37, s. 243-254. 


\section{Streszczenie}

W artykule przedstawiono standardy postępowania w przypadku diagnozowania jakości emisji głosu. Omówiono stosowane narzędzia diagnostyczne, między innymi test VHI, skalę dyskomfortu traktu głosowego YTD, odsłuchową skalę GRBAS. Główną część artykułu stanowi opis wywiadu ustrukturyzowanego, który może być stosowany podczas rozmowy (diagnozy) przez specjalistów, między innymi laryngologów, foniatrów, logopedów czy trenerów emisji głosu. Wywiad obejmuje szereg pytań z zakresu: danych podstawowych, warunków i higieny pracy, nawyków zdrowotnych, stanu zdrowia, problemów głosowych, jak również zmiennych psychologicznych. Do wywiadu skonstruowano arkusz, który ułatwia prosty i szybki zapis zgromadzonych wyników.

\section{Abstract}

The article presents the standards of conduct in case of diagnosing the quality of voice emission and discusses such diagnostic tools as the Voice Handicap Index (VHI), Applicability of the Vocal Tract Discomfort (YTD scale) or the GRBAS scale. The main part of the article is a description of a structured interview which can be used during a conversation (diagnosis) by specialists: phoniators, speech therapists or voice trainers. The interview includes a number of questions in the field of basic data, occupational health and hygiene, health habits, health status, problems with voice as well as psychological variables. The tool is accompanied by a sheet in which you can record the obtained answers. 